\title{
Community Participations in Comprehensive Planning of Amphawa District, Thailand
}

\author{
Wannasilpa Peerapun \\ Faculty of Architecture, \\ Chulalonkorn University, Thailand \\ wannasilpa.p@chula.ac.th
}

\begin{abstract}
The aim of this article was to discuss community participations in comprehensive planning of Amphawa District, Thailand, which targeted for the year 2030. There were two objectives of the study: to discuss the effectiveness of community participations and to discuss the future land use plan. The planning methodology integrated several community participation activities into the traditional comprehensive planning process. The result of the study revealed that community participations helped reduce difficulties and save time. In terms of future land uses, several conservation related zones were designated to conserve local natural and cultural heritages and agricultural areas.
\end{abstract}

Keywords: Community participations; Comprehensive planning; Amphawa District

eISSN 2398-4279 @ 2018. The Authors. Published for AMER ABRA cE-Bs by e-International Publishing House, Ltd., UK. This is an open access article under the CC BY-NC-ND license (http://creativecommons.org/licenses/bync-nd/4.0/). Peer-review under responsibility of AMER (Association of Malaysian Environment-Behaviour Researchers), ABRA (Association of Behavioural Researchers on Asians) and cE-Bs (Centre for EnvironmentBehaviour Studies), Faculty of Architecture, Planning \& Surveying, Universiti Teknologi MARA, Malaysia.

DOI: https://doi.org/10.21834/ajqol.v3i12.139 


\subsection{Introduction}

Comprehensive planning in Thailand is a very complicate task which requires many steps mandated by law and a lengthy procedure outlined by ministerial and departmental orders. Community participations in general comprehensive planning are usually limited. Public hearings are usually held after the draft plan is completed, not during the stage of planmaking. The lack of appropriate community participation procedure and tools have increased difficulties in the process of comprehensive planning in Thailand. More conflicts have arisen frequently resulting in negative attitudes of local citizens towards comprehensive planning.

Comprehensive planning of Amphawa District, targeting for the year 2030, attempted to deal with the problems of community participations in Thailand. Covering an area of 169 square kilometers, the planning area comprised several small municipalities and subdistricts, orchards, fish ponds, mangroves and intensive water networks. Participatory action research approach was integrated into the comprehensive planning procedure mandated by the Office of Public Construction and Town Planning while the core planning concept inherited "the Philosophy of Sufficiency Economy" initiated by H.M. King Bhumibol and UNESCO's sustainable development dimensions.

The aim of this article was to discuss community participations in comprehensive planning of Amphawa Distrct. There were two objectives of the study: to discuss the effectiveness of community participations and to discuss the future land use plan.

\subsection{Literature Review}

Comprehensive plans have become common for urban and rural areas because the development is complex, development decisions are interrelated, and the development process could be improved through careful analysis, foresight, and planning (Knaap \& Chakraborty, 2007, p. 19). Successful comprehensive community planning processes are those that are community-driven and all sectors of the community should have an opportunity to participate (Minister of Indian Affairs and Northern Development, 2006, p. 9). Grabow \& Hilliker (2006, p. 27) proposed five different levels of involving citizens in the comprehensive planning process: public awareness (lowest level), public education, public input, public interaction and public partnership (highest level). Several participation techniques were proposed in CCP HANDBOOK Comprehensive Community Planning for First Nations in British Columbia. Some interesting ones included focus groups, citizen advisory committee, visioning, and citizen planning committees. (Minister of Indian Affairs and Northern Development Ottawa, 2006, pp. 35-48). In Amphawa urban conservation and regeneration projects, it was found that publications and community workshops were very effective tools in several planning stages (Peerapun, 2012, p.40).

Sustainable development is the ultimate goal of comprehensive planning. In Thailand, "the Philosophy of Sufficiency Economy" initiated by H.M. King Bhumibol has been officially adopted and applied to various types of planning. It is the philosophy which stresses three principles in all mode of conduct: moderation, reasonableness and self-immunity (Miller \& Tinio-Le Douarin, 2013, p. 14). Two conditions are needed to make these principles work: knowledge and morality. Knowledge encompasses accumulating information with insight to 
understand its meaning and the prudence needed to put it to use while morality refers to integrity, trustworthiness, ethical behaviour, honesty, perseverance, and a readiness to work hard (Mongsawad, 2010, p. 128).

Another interesting sustainable development model is the one developed by UNESCO (n.d.). It comprises three stacked circles. The middle circle indicates the four dimensions of development: natural, economic, social, and political aspects. The inner circle indicates four major issues associated with the four aspects. The outer layer indicates four means of development: conservation, appropriate development, peace in combination with equity and human rights, and democracy (Peerapun, 2012, p. 38).

\subsection{Methodology}

The methodology for comprehensive planning of Amphawa District incorporated significant community participation activities and sustainable development concepts into Thai traditional comprehensive planning process outlined by the Department of Public Construction and Town and Country Planning, Ministry of Interiors (fig. 1).

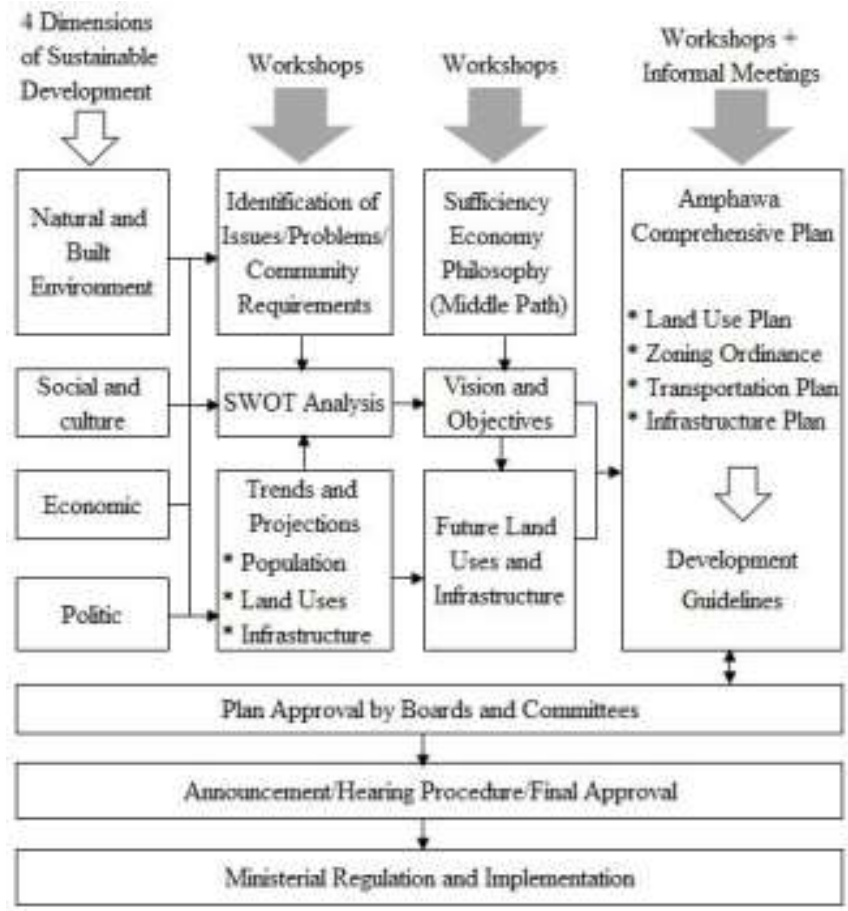

Figure 1: Amphawa Comprehensive Planning Methodology (Source: Compiled by the authour) 
Mandating by law, a small advisory board was established to act as a planning consultant and help monitor the progress of comprehensive planning. In terms of community participations, only public hearings at the beginning and the end of the planning process were required. To increase the level of community participations, several participation activities were added to the regular planning processes. Community workshops and related activities such as visioning and mapping were adopted as general community participation techniques. Due to budget constraint, the number of participants was limited. A working group, comprising 40 local administrators and delegates from all communities in the planning area, was formed to participate in planning workshops. Several informal meetings with local administrators and chiefs of sub-districts and villages were held to enhance community collaborations. Data on the natural and built environment dimension were collected mostly from field surveys and feedbacks from the workshops. Data on other dimensions were collected mostly from secondary data and community feedbacks.

Four dimensions adapted from UNESCO's sustainable development model-natural and built environment, economic, social and culture, and politic-were placed at the stage of data analysis. The Philosophy of Sufficiency Economy was placed at the stage of visioning. These concepts helped shape the scope and directions for Amphawa's future development.

\subsection{Results and Discussion}

Amphawa District covers an area of 169 square kilometers or 41 percent of Samut Songkhram Province. It is located in the western part of Thailand, about 72 kilometers from Bangkok. In 2010, orchards and other agricultural areas accounted for 69 percent of land uses, following by fish and shrimp ponds ( 14 percent), mangroves ( 8 percent) and waterways (4 percent). Residential areas shared only 3 percent while infrastructure and others shared the rest of land uses in Amphawa District (Faculty of Architecture, C.U., 2013, p. 4/27). Land transportation via small road networks was the major transportation mode while water transportation was used mostly for tourism purposes. There were 56,755 registered inhabitants in Amphawa District in 2010 (Faculty of Architecture, C.U., 2013, p. 4/27). In terms of tourism development, there were 558,326 visitors coming to Amphawa District 2007 (Peerapun \& Silapacharanan, 2011, p. 174).

\subsection{The effectiveness of community participations in comprehensive planning of Amphawa District}

Stakeholders engaging in Amphawa comprehensive Planning could be classified into two groups as follows:

1) Committees appointed by law and ministerial orders from local, provincial, sub-national and national levels. A small local advisory board was appointed to follow up every planmaking stage. After a draft comprehensive plan had been completed, it had to get approval from Provincial Town and Country Planning Subcommittee, Town and Country Planning Subcommittee and Town and Country Planning Committee respectively.

2) Community participants who participated in various plan-making stages. The law only required a public hearing after the draft comprehensive plan was completed, not during plan- 
making stages. To cope with the problem, real community participation activities were added to comprehensive planning of Amphawa Community. A working group comprising 40 members of all mayors, all chief-executives of sub-districts, and delegates from all communities in Amphawa District was formed to participate in planning development.

Several planning workshops were arranged utilizing some successive planning tools learned from Amphawa conservation and regeneration projects. In addition, several informal meetings were arranged with all local administrators, sub-district chiefs and village chiefs to discuss and follow up the comprehensive plan.

Working group participations were very effective in the stage of plan-making. By dividing participations into small groups and using community mapping technique, alternative future land use maps were quickly developed. Informal meetings with local administrators, subdistrict chiefs, and village chiefs were also very effective. With their helps, it was easy to explain the plan to the citizens. The feedback from the meetings was very good. The subdistrict chiefs and village chiefs felt positive to be part of community participants in comprehensive planning because their opinions were taken into account during plan-making stage.

After the draft comprehensive plan of Amphawa District had been completed, it was presented to the Provincial Town and Country Planning Subcommittee for approval. The effectiveness of having local administrators in the working group was obvious at this stage. Since they had participated in plan-making stage, they strongly supported the plan. As a result, the comprehensive plan of Amphawa District was quickly approved by the Provincial Subcommittee.

There were some difficulties for the comprehensive plan of Amphawa District to get approval from the National Town and Country Planning Subcommittee because many changes were made to land use plan and road network specified in the expired Amphawa comprehensive plan. With the supports from local administrators, however, the problem of land use changes was resolved after the subcommittee made a trip to Amphawa and saw the situation there. There were no problems with road cancellation, but some with road size reductions. The transportation expert of the subcommittee suggested that the roads should be wider to cope with future demands. The problems were solved via informal consultation with the expert. The new road sizes were altered to be wider than the original draft plan but narrower than the expert's original suggestion.

Public hearing was conducted after the draft comprehensive plan was approval by the Town and Country Planning Subcommittee. Although several roads proposed in the expired comprehensive plan were canceled, some of them had to remain to support future land development and increasing cars. Some local residents did not want any roads to pass their lands for fear that their lands might be appropriated. The subcommittee did not agree with them and insisted that the road network should follow the ones proposed in the draft comprehensive plan. Although there were some problems with future transportation plan, the comprehensive plan of Amphawa District took a shorter time and had fewer problems than other comprehensive planning to get approval. 


\subsection{Amphawa future land use plan}

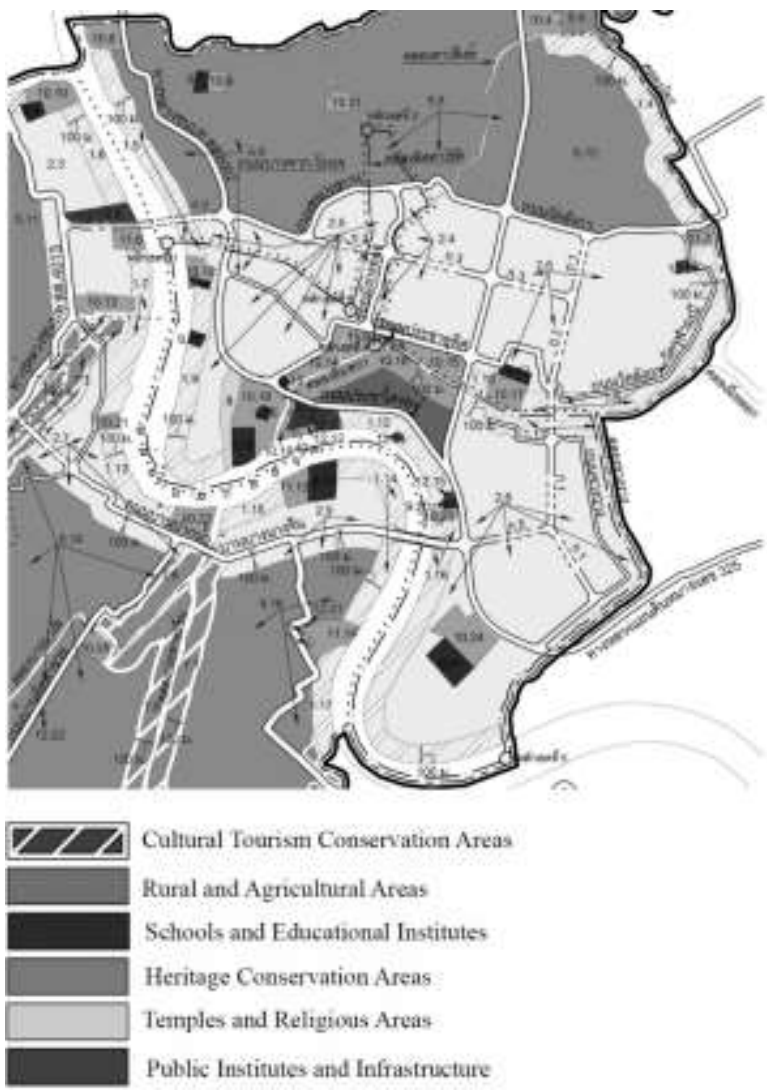

Fig. 2: Future land uses of Amphawa Municipality and surrounding areas in the comprehensive plan of Amphawa District

Source: Faculty of Architecture, C.U. (2013) p. 7/2).

The comprehensive plan of Amphawa District for the year 2030 covered the whole Amphawa District. The number of population was projected to be 85,152 and the number of tourists coming to the area was projected to be 884,787 . (Faculty of Architecture, C.U., 2013, p. 4/24). The main idea of Amphawa future land use plan was based upon the vision centered by the Philosophy of Sufficiency Economy. Moderate development was identified as balancing new development with traditional land use and transportation patterns. Sustainable development was identified as conserving traditional waterfront settlements, orchard, ditch networks, and natural and cultural heritages while recognizing new development as part of Amphawa future. Conservation-related areas and new development 
areas for future needs were designated to co-exist with each other. Only new land uses which meet vision requirements were allowed.

The new comprehensive plan of Amphawa District addressed the significance local identities and the needs for conservation of heritage places and cultural tourist attractions. Several conservation related areas were designated to keep existing land use patterns. Land uses were classified into two groups. The first group focused on conservation of existing settlement patterns, cultural heritages, cultural tourism, and agricultural areas. The second group focused on corresponding development for future needs. To keep existing land use patterns, the heights and the sizes of new buildings were limited.

Many changes were made to road network and road sizes proposed in the expired comprehensive plan. Several roads and bridges cutting through waterfront communities and Amphawa Canal were taken out to conserve the waterfront community while the widths of several roads were reduced to minimize the needs for land appropriations and the destruction of ditch systems. As mentioned earlier, there were some difficulties in doing so and the problems were solved via informal consultation with the expert and following the concept of the middle path from the Philosophy of Sufficiency Economy to get the solution.

\subsection{Discussion}

Although there were budget, time and procedural limitations, community participants in comprehensive planning of Amphawa District were intensive. The number of participants may seem small at the beginning but it proved to be a manageable size. Participants had enough time to express their concerns in visioning and plan-making stages. Planning workshop proved to be a very effective tool. In combination with SWOT analysis, visioning and community mapping, the workshops always ended up with useful and reliable outcomes. The roles of the planner were significant to the success of planning development, however. At the beginning of the planning process, the planner played the role of mentor and coordinator. At the visioning stage, the planners became inquirers and summarizers. At the plan-making stage, the planner became the leader and coordinator of the team. A small working group was more effective when dealing with area based issues and plans while a large working group was more effective when dealing with data assembly and plan assembly.

It was found that the combination of local administrators and community delegates came out right. Conflicts with local administrators, which usually happened in general comprehensive planning, were totally solved. Informal meetings with local administrators, chiefs of sub-districts and village chiefs were very useful in terms of seeking for local supports and reducing conflicts.

Community participations were very effective for comprehensive planning of Amphawa District because they helped reduce conflicts and save time. Amphawa future land use plan was unique in terms of designating several conservation related zones and proposing small road network. The plan was made possible with the support of the communities which was the result of community participations in various stages. Applying community participations in Thai comprehensive planning had a limitation, however. Due to the nature of Thai comprehensive planning practices, plan approval was undertaken by committees appointed by central government. Since community participations could not happen at this stage, the 
highest level of citizen involvements in comprehensive planning-public partnershipproposed by Grabow \& Hilliker (2006, p. 27) could not be reached. In the case of Amphawa comprehensive planning, it was found that the level of citizen involvement could be elevated from public awareness founded in traditional comprehensive planning to public input and public interaction.

\subsection{Conclusion}

Comprehensive planning of Amphawa District for the year 2030 was a big step of community participations in Thai comprehensive planning. Community participations were raised from the lowest level of citizen participations to nearly the highest level. The effectiveness of community participations in comprehensive planning of Amphawa District was praised by Town and Country Planning Committee during a committee meeting to approve Amphawa comprehensive plan. The committee made the following comments:

The comprehensive plan of Amphawa District was undertaken in accordance with citizen participations. With the supports from local administrators and citizens, the plan was obviously developed to reduce population density. This reflected citizens' awareness of traditional community conservation. The plan also proposed guidelines for planning implementation which should be developed into action area plans. These good things should be a model for other comprehensive planning in the future. (Town and Country Planning Committee, 2013, p. 11)

The value of community participations in comprehensive planning of Amphawa District not only came from the effectiveness in terms of time saving and consensus buildings but also came from the ability to draw people to come together to envision the future of their communities. Comprehensive planning of Amphawa District offered useful lessons for comprehensive planning in Thailand. The lessons were not fully completed and required further study. More participation techniques and tools should be tested in future comprehensive planning and best combinations of techniques and tools should be addressed.

\section{Acknowledgement}

The author gratefully acknowledge Samut Songkhram Province and Samut Songkhram Town and Country Planning Office for their helps and financial supports and all participants for their cooperation and contributions in the comprehensive planning of Amphawa District.

\section{References}

Amphawa Comprehensive Plan (2nd revision), Amphawa District, Samut Songkhram Province. Bangkok: Author.

City of Greensburg. (2008). Greensburg Sustainable Comprehensive Plan. City of Greensburg: Kansus+BNIM. Faculty of Architecture, C.U. (2013). 
Grabow, S.H. \& Hilliker, M. (2006). Comprehensive Planning and Citizen Participation. UW Extension: Board of Regents of the University of Wisconsin System.

Knaap, G. \& Chakraborty, A. (2007). Comprehensive Planning for Sustainable Rural Development. JRAP. 37(1), 18-20.

Miller, M. \& Tinio-Le Douarin, M.L. (Eds.). (2013). Towards a Sufficiency Economy: A New Ethical Paradigm for Sustainability. Paris: the United Nations Educational, Scientific and Cultural Organization.

Minister of Indian Affairs and Northern Development Ottawa. (2006). Comprehensive Community Planning Handbook. Minister of Public Works and Government Services Canada.

Mongsawad, P. (2010). The Philosophy of the Sufficiency Economy: A Contribution to the Theory of Development. Asia-Pacific Development Journal. 17(1), 123-143.

Peerapun, W. \& Silapacharanan, S. (2011). Conservation and Regeneration of Amphawa Community. In Chulalongkorn University, Sufficiency Economy Vol. 2, pp. 153-184. Bangkok: Chulalongkorn University Press.

Peerapun, W. (2012). Participatory Planning Approach to Urban Conservation and Regeneration in Amphawa Community, Thailand. Asian Journal of Environment-Behaviour Studies. 3 (7). 35-44.

Peerapun, W. (2017). Community Participations in Amphawa Comprehensive Planning, Thailand. EnvironmentBehaviour Proceeding Journal, 2(5), 41-48.

Town and Country Planning Committee. (2013). Minute No. 2/2013. Friday 25thJanuary 2013, Rancho Room, Chanwee resort and Country Club, Nakhon Ratchasima Province.

UNESCO. (N.D.). Four Dimensions of Sustainable Development. Retrieved November 20, 2016 from http://www.unesco.org/education/tlsf/TLSF/theme_a/mod04/ uncom04t01s03.htm 